\title{
Phytoextraction of Nutrients and Heavy Metals by two Monocot Plants in Thaulla Area of Small Reservoir in Anuradhapura, Sri Lanka
}

\author{
N. S. Abeysingha ${ }^{1 *}$, K. H. R. S. Maduranga ${ }^{1}$, Suryendra Singh ${ }^{2}$ and D. M. S. Duminda ${ }^{1}$ \\ Date Received: $15^{\text {th }}$ October 2019 / Date Accepted: 21 $1^{\text {st }}$ March 2020
}

\begin{abstract}
Purpose : Small tanks/reservoirs are one of the major components of dry zone landscape and they were the basis of prosperity in ancient Sri Lanka. There are identified ecosystem components associated with the tanks such as upper peripheral area (thaulla). It is useful to understand the role of hydrophytes in thaulla area scientifically. This field study aimed to investigate the phytoextraction ability of two monocot plants, Paspalidium punctatum and Cyperus rotundus naturally grown in thaulla area of Ulankulama tank located in Anuradhapura.
\end{abstract}

Research Method: The accumulation of total $N, P, K, C a, M g, C d, P b$ and $A s$ were assessed by getting both plant and soil samples from 20 sampling points in thaulla area. Total $\mathrm{K}, \mathrm{Ca}, \mathrm{Mg}, \mathrm{As}, \mathrm{Cd}$, and $\mathrm{Pb}$ contents were measured using the Inductivity Couple Plasma Optical Emission Spectrophotometer (ICP-OES) procedure. N, P, K were assessed following standard analytical procedures.

Findings : Results showed that As and Cd were not observed in detected amount in soils of root zone of the plants. However, As and Cd were present in shoots and roots in both plant species. Both species could be considered as hyperaccumulator for $\mathrm{K}, \mathrm{Ca}$ and $\mathrm{Mg}$ as they have biological concentration factor higher than one.

Originality/Value: Paspalidium punctatum and Cyperus rotundus could be considered as hyperaccumulator for $\mathrm{K}, \mathrm{Ca}$ and $\mathrm{Mg}$ and bio accumulation of heavy metals in thaulla area.

Keywords: Heavy metals, Nutrients, Phytoextraction, Thaulla, Small tank

\section{INTRODUCTION}

Excessive use of agrochemicals and chemical use in industries lead to dispose metal containing pollutants and have accumulated in soil especially, heavy metals and plant nutrients such as phosphorus. Even in dry zone environment in Sri Lanka, use of agrochemical is still the main method of controlling pests and synthetic fertilizer is the main source of crop nutrients. The residues of agrochemicals containing metals and excess plant nutrients directly reach water bodies through the runoff as they reside in low lying area of the dry zone landscape. In addition, different kinds of industries are emerging and the use of vehicles are in increase in dry zone Sri Lanka and their chemical effluent containing different kinds of metals are very likely to ultimately dispose to water bodies. Water bodies in the dry zone are mainly manmade and are called as tanks. Of all the small tanks in the dry zone, approximately 90 percent is clustered into the cascades (Wijesundara et al., 2012).

"A 'tank cascade' is a connected series of tanks organized within a meso catchment of the dry zone landscape, storing, conveying and utilizing water from an ephemeral rivulet" (Madduma Bandara,1985). As this system is adapted agricultural system managed with time tested

\footnotetext{
I Department of Agricultural Engineering and Soil Science, Faculty of Agriculture, Rajarata University of Sri Lanka, Puliyankulama, Anuradhapura, Sri Lanka.

nabeysingha@gmail.com

Guru Angad Dev Veterinary and Animal Sciences University, Ludhiana (Punjab) India.
}

(1) ORCID http://orcid.org/0000-0003-4635-3285 
indigenous techniques, FAO (2018) recognized this system as a Globally Important Agricultural Heritage System. In this system, water discharged from the upper tank to the command area, flood water of the upper tank and water draining from the paddy fields in the upstream command area are captured by the tank at downstream which flow through thaulla area (Abeysingha et al., 2018). This micro-land region of the tank is partially covered with water but only completely flooded mostly during the rainy season particularly, during the North East monsoon season. However, this area is comparatively dry during the dry season (May to September) especially, in tanks located in North Central Province where there is no Mahaweli water diversions. Mahatantila et al., (2008) suggested that most of the water pollutant draining into tank can be effectively controlled by the thaulla taking Malagane tank as an example. Abeysingha et al.( 2016) showed that $\mathrm{Mg}, \mathrm{Na}$, and $\mathrm{Ca}$ in a decreasing concentration in soils of thaulla area towards the water spread area in Ulankulama tank at Maradankadawala in Anurahdapura and also shown that metal concentration is higher in thaulla area when compared to the normal values of the surrounding soils (Gunapala and Abeysingha, 2019). These results suggest that thaulla, can act approximately as an active 'constructed wetland' which efficiently removes pollutants in order to sustain the system. Thaulla area along with a small tank environment can be considered as a special wetland system (Gunapala and Abeysingha, 2019).

In wetlands, there is a close link between the aquatic flora and the soil and water conditions, being complex systems in which the exchange between soil and biota is accomplished in dilute media and sometimes in reducing environment, providing environments that differ from most soil surface horizons, which are usually under aerobic conditions (Cacador et al., 2013). In addition, wetlands have an important role in the preservation of environmental quality due to their high capacity for retention and/or inactivation of harmful substances (González-Alcaraz et al., 2013). Aquatic macrophytes not only assimilate pollutants directly into their tissues, but can also act as catalysts for purification reactions by increasing environmental diversity in the rhizosphere, thereby promoting various chemical and biochemical reactions that enhance purification (Jenssen et al., 1993). Approximately, similar functions can be expected in tank- Thaulla a partial wetland ecosystem. In this partial wetland ecosystem there are different kinds of hydrophytes. Understanding their roles is useful to conserve the thaulla area of tanks further in future. According to the published literature, there were no scientific studies to quantify the phytoextraction abilities of naturally grown hydrophytes in thaulla area. Therefore, this research study is planned to quantify the nutrients and heavy metals absorbing capabilities of most abundant two monocots plants naturally growing in thaulla area of a small tank.

\section{METHODOLOGY}

\section{Study Site and Sampling Procedure}

The field work was carried out in Thaulla area of Ulankulama tank, located in Tirappane Divisional Secretariat Division in Anuradhapura district, North Central Province. This tank is located about $20 \mathrm{~km}$ south from Anuradhapura city, closer to the Anuradhapura - Maradankadawala - Kekirawa road. It is found in the middle part of Ulagalla cascade which has a prominent thaulla area of about $0.43 \mathrm{~km}^{2}$ in extent (Abeysingha et al., 2016). Figure 01 shows the geographical location of the tank and sampling points.

As shown by Gunapala and Abeysingha (2019), the soil properties vary from upstream area to downstream area of thaulla. Therefore, sampling points were selected to represent this variation as shown in the Fig.01. In this study, only one type of dominant sedge and grass were selected and mature plants of both sedge and grass were uprooted from approximately one meter radius of the sampling points. Sampling points had to be limited to 20 sites due to limited availability of same grass and sedge. Soil samples were taken from the same place where plants are uprooted and the same root zone depth of the plants of about $0-15 \mathrm{~cm}$. These soil and plant samples were transferred into pre-cleaned, labeled polythene bags separately. 


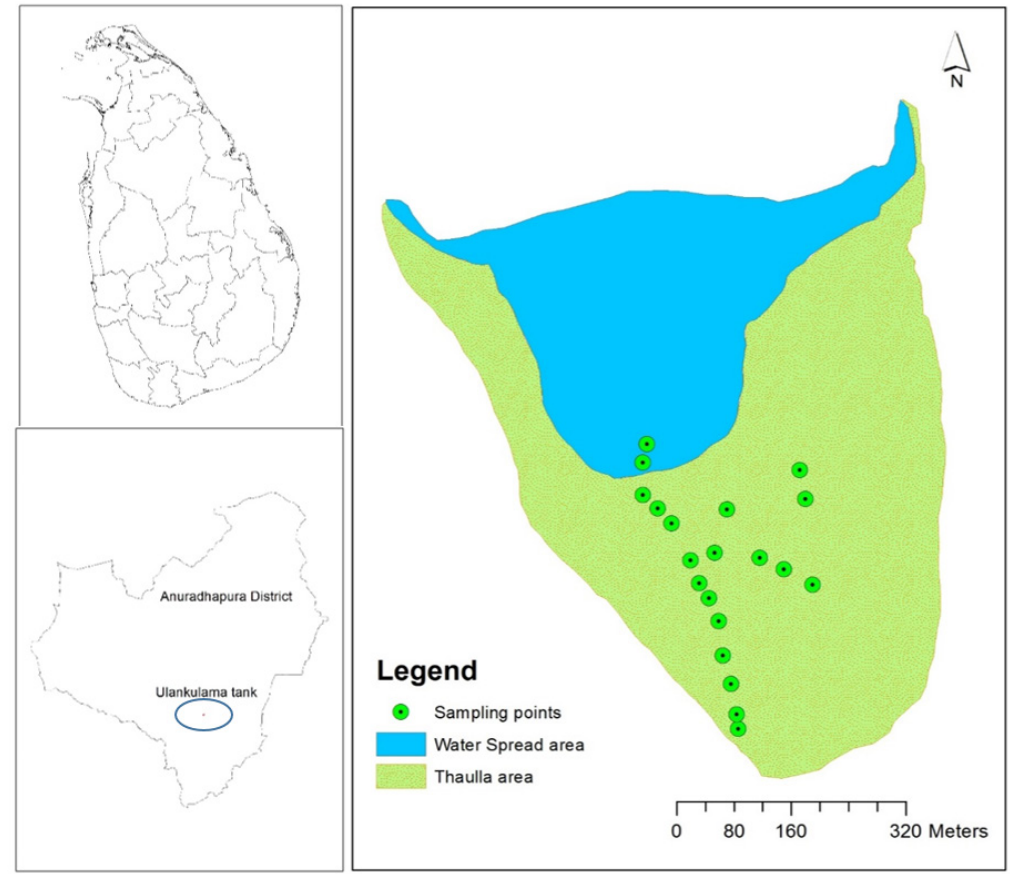

Figure 01: Ulankulama tank located in Anuradhapura District and Thaulla area and sampling points

Subsequently, samples were subjected to analysis of nutrients and heavy metals. Meanwhile, two monocot plant species ie. sedge and grass collected were identified with the support of the National Herbarium, Peradeniya Sri Lanka. Two monocot species were identified as Cyperus rotundus and Paspalidium punctatum a sedge and grass respectively.

\section{Analytical determinations}

In the laboratory, individual plant samples were first washed thoroughly in running water to avoid any surface contamination and then rinsed with distilled water to remove any further residual materials. Then plant samples were dissected into roots and leaves and air dried for 2 to 3 days and oven dried them in $60{ }^{\circ} \mathrm{C}$ for 2 days. Plant samples were ground in an agate mortar to ensure a homogeneous element distribution in the powder. All soil samples were air-dried separately without allowing contamination with external material or among samples. Soil samples were air dried at room temperature on polythene sheet. While drying aggregates were broken by crumbling the lumps. Plant roots and stone particles were removed. Then, the collected soil samples were ground using a hammer. Then, soil passed through a $2 \mathrm{~mm}$ sieve and sieved soil samples were stored in clean polythene bags after proper labeling. Then both soil and plant samples were analyzed for total N, P, K, Ca, Mg and heavy metals $\mathrm{Cd}$, As and $\mathrm{Pb}$. Then, $\mathrm{pH}$ and EC of soil samples were also tested.

Total $\mathrm{K}, \mathrm{Ca}, \mathrm{Mg}, \mathrm{As}, \mathrm{Cd}$, and $\mathrm{Pb}$ contents were measured using the Inductivity Couple Plasma Optical Emission Spectrophotometer (ICP-OES) procedure after acid digestion of soil samples and dry ashing of plant samples (SERAS, 2006). $\mathrm{pH}$ and EC of soil samples were determined using the multi-parameter analyzer $(\mathrm{HATCH}$, Sension 156) with the 1:2.5 soil-water suspension method (Rowell 1994) and 1: 5 soil-water suspension method (Chapman and Pratt 1961) respectively. Total N content of soil samples were determined through the Kjedahl procedure (Bremmer and Muloaney 1982). Total $P$ in soil was measured by wet oxidation method (Akinremi et al., 2003) and $\mathrm{P}$ in plant samples were determined after dry ashing of plant samples.

Bio concentration/ Biological accumulation and translocation factors were determined to assess element mobility in the studied species. The values obtained were based on the following

$\mathrm{BAF}=\mathrm{NC}$ shoot $: \mathrm{NC}$ soil 
$\mathrm{BTF}=\mathrm{NC}$ shoot $: \mathrm{NC}$ root

$\mathrm{BCF}=\mathrm{NC}$ root $: \mathrm{NC}$ soil

BAF- Biological accumulation factor

BTF- Biological translocation factor

BCF- Biological concentration factor. (Yoon and $\mathrm{Li}, 2007$ )

To test the significant differences between mean values of different elements in both soil and plant and ratios (BAF, BTF and BCF), data were subjected to one-way analysis of variance $(p<$ $0.05)$ with a mean separation of least significant difference (LSD) value.

\section{RESULTS AND DISCUSSION}

Different plants species have different capacities to accumulate the nutrients and toxic heavy metals from various wet environments which is an indicator of their potential phytoremediation action. This study tested accumulation of few nutrients and heavy metals in Paspalidium punctatum and Cyperus rotundus which were abundant in meadow of tank Ulankulama.

Results indicated that $\mathrm{N}$ content was significantly higher in shoots than the roots in both the monocot plant species Paspalidium punctatum, and
Cyperus rotundus. However, $\mathrm{N}$ content in both roots and shoots was not significantly different between two plant species (Table 01). Also, soil $\mathrm{N}$ content was not significantly different from places where the plants were uprooted (Table 02). These results infer that both grass and sedge tested has approximately same capacity to accumulate nitrogen and more nitrogen is located in shoots than roots. Soil nitrogen content varies from 0.132 to $0.146 \%$ at the root zone area and these values are lower than the general soil in the area of Anuradhapura district' soil which is Reddish Brown Earth (RBE) and it is associated with Low Humic Glay (LHG) soil and N content varies from $11.6 \%$ to $23.22 \%$ ( Nandasena 2002). $\mathrm{N}$ is the most limiting nutrient in wetland system (Reddy and D'Angeolo, 1997) and thaulla area was also observed with limited nitrogen compared to the reference soil. N. Gunapala and Abeysingha (2019) also observed the lower $\mathrm{N}$ contents $(0.073 \%)$ in the entire Thaulla area of the same tank, Ulankulama. Wetland plants have special physiological processes such as cluster roots to accumulate essential nutrients such as $\mathrm{N}$ and $\mathrm{P}$ (Zedler, 2010). Thaulla in small tanks can be considered approximately as a wetland (Abeysingha et al., 2018). Lower concentration of $\mathrm{N}$ reported in the present study also supports the hypothesis that the Thaulla can act partially as a wetland.

Table 01: $\quad$ Nutrient and heavy metal content of Paspalidium punctatum and Cyperus rotundus

\begin{tabular}{lcccc}
\hline \multirow{2}{*}{ Parameter } & \multicolumn{2}{c}{ Paspalidium punctatum } & \multicolumn{2}{c}{ Cyperus rotundus } \\
\cline { 2 - 5 } & Shoot & Root & Shoot & Root \\
\hline $\mathrm{N} \%$ & $0.09^{*} \pm 0.04$ & $0.05 \pm 0.03$ & $0.07^{*} \pm 0.02$ & $0.04 \pm 0.01$ \\
$\mathrm{P}(\mathrm{mg} / \mathrm{kg})$ & $33.83 \pm 14.27$ & $23.13 \pm 8.46$ & $36.91 \pm 14.25$ & $22.84 \pm 5.03$ \\
$\mathrm{~K}(\mathrm{mg} / \mathrm{kg})$ & $186.19 \pm 133.66$ & $125.12 \pm 104.57$ & $207.50 \pm 41.33$ & $141.08 \pm 49.50$ \\
$\mathrm{Ca}(\mathrm{mg} / \mathrm{kg})$ & $37.02 \pm 7.66$ & $34.83 \pm 10.99$ & $41.94 \pm 5.77$ & $39.04 \pm 7.62$ \\
$\mathrm{Mg}(\mathrm{mg} / \mathrm{kg})$ & $25.08 \pm 6.55$ & $21.33 \pm 7.94$ & $28.91 \pm 9.1$ & $22.61 \pm 7.2$ \\
\hline $\mathrm{Heavy} \mathrm{metal}$ & & & & \\
\hline $\mathrm{Cd}(\mu \mathrm{g} / \mathrm{kg})$ & $0.001 \pm 0.001$ & $0.002 \pm 0.001$ & $0.002 \pm 0.001$ & $0.002 \pm 0.001$ \\
$\mathrm{As}(\mu \mathrm{g} / \mathrm{kg})$ & $0.808 \pm 0.20$ & $1.158 \pm 0.38$ & $0.820 \pm 0.16$ & $1.286 \pm 0.36$ \\
$\mathrm{~Pb}(\mu \mathrm{g} / \mathrm{kg})$ & $0.18 \pm 0.05$ & $0.25^{*} \pm 0.06$ & $0.141 \pm 0.03$ & $0.170 \pm 0.06$ \\
\hline
\end{tabular}

*Significantly different at $P<0.05$; mean values $( \pm S D)$ 
Table 02: Nutrient and heavy metal content of root zone soil under Paspalidium punctatum and Cyperus rotundus

\begin{tabular}{lcc}
\hline \multicolumn{1}{c}{ Parameter } & Paspalidium punctatum & Cyperus rotundus \\
\hline $\mathrm{N} \%$ & $0.132 \pm 0.08$ & $0.146 \pm 0.05$ \\
$\mathrm{P}(\mathrm{mg} / \mathrm{kg})$ & $47.314 \pm 17.24$ & $35.575 \pm 10.14$ \\
$\mathrm{~K}(\mathrm{mg} / \mathrm{kg})$ & $9.357 \pm 1.90$ & $8.432 \pm 1.76$ \\
$\mathrm{Ca}(\mathrm{mg} / \mathrm{kg})$ & $17.176 \pm 4.75$ & $23.03^{*} \pm 2.60$ \\
$\mathrm{Mg}(\mathrm{mg} / \mathrm{kg})$ & $14.12 \pm 3.33$ & $21.66^{*} \pm 3.46$ \\
$\mathrm{Cd}(\mathrm{ppb})$ & $\mathrm{ND}$ & $\mathrm{ND}$ \\
$\mathrm{As}(\mathrm{ppb})$ & $\mathrm{ND}$ & $\mathrm{ND}$ \\
$\mathrm{Pb}(\mathrm{ppb})$ & $33.75 \pm 13.81$ & $27.9 \pm 9.33$ \\
$\mathrm{pH}$ & $6.34 \pm 0.56$ & $6.34 \pm 0.48$ \\
$\mathrm{EC}(\mu \mathrm{S} / \mathrm{cm})$ & $151.99 \pm 49.64$ & $158.00 \pm 43.81$ \\
\hline
\end{tabular}

Note: mean values $( \pm S D)$

$\mathrm{P}$ and $\mathrm{K}$ contents of studied plants were also higher in shoots of both the plants and they were not significantly different between both plant species. Though both $\mathrm{Ca}$ and $\mathrm{Mg}$ contents were higher in shoots than those of roots, they were not statistically different in both the plant species and between both two plants. Out of the nutrients parameters tested, $\mathrm{K}$ absorbed by both plants more than other elements. However, the most abundant nutrient in the thaulla area was $\mathrm{P}$ (Table 02). The total P concentration of RBE soils in Anuradhapura district varied from 1.6 to $20 \mathrm{mg} / \mathrm{kg}$ (Karunadasa and Duminda, 2013). This study observed the P accumulation (35 to $47 \mathrm{mg} / \mathrm{kg}$ ) in soils in the root zone area of part of thaulla area probably due to higher use of $\mathrm{P}$ fertilizer in the tank catchment area. Contents of other nutrients in soil are shown in Table 02 and these values are not significantly different under two plant types except $\mathrm{Ca}$ and $\mathrm{Mg}$. $\mathrm{Ca}$ and $\mathrm{Mg}$ concentration was higher in soil associated with the sedge (Cyperus rotundas) and it may be due to root exudates of the sedge or the inherent soil properties. Moreover, $\mathrm{Ca}$ and $\mathrm{Mg}$ contents are higher in both the shoots and roots of sedge than the grass though the values are not statistically significant.

Wetland can effectively remove heavy metals and metalloids in water by acting as a matrix, facilitating interaction between microbes and plant/animal communities and performing functions such as filtration, adsorption, precipitation, ionic exchange, microbiological degradation, and biological uptake (Malaviya and Singh, 2012). Cd and As in root zone area of Thaulla soil were not detected while, $\mathrm{Pb}$ was detected in higher quantities (Table 02) in soils associated with root zone area of both the plant species. Bioaccumulation of metals is determined by $\mathrm{pH}$ of the substrate, plant type, climatic conditions, and form and state of available metals in the substrate (Maiti and Jaiswal, 2008). It is observed that a higher release rate of heavy metals exists in the sediment-water system at lower $\mathrm{pH}$ than higher $\mathrm{pH}$ ( Li et al., 2013). $\mathrm{pH}$ of the studied thaulla soil was slightly acidic (Table 02) and that may result in higher release of heavy metals from the soil system. Three heavy metals tested were observed in both plants and present in both shoots and roots. Though As and Cd were not present in detected amount (ICP-OES method) in soils, presence of $\mathrm{As}$ and $\mathrm{Cd}$ in shoots and roots may be due to higher release rate of the soil and their bio accumulation in plants. Concentration of As was higher than the $\mathrm{Pb}$ and $\mathrm{Cd}$ both in roots and shoots. As and $\mathrm{Pb}$ contents are higher in roots than those of shoots in both the species. Only $\mathrm{Pb}$ is significantly higher in roots than those of shoots in grass. Greater accumulation of 
trace element in underground organ is a common pattern as a defensive mechanism to protect the species against harmful toxic effects (Bonanno, 2013; Phillips et al., 2015).

Biological translocation, Biological concentration and Biological accumulation factors of nutrient and heavy metals are shown in Table 03. Biological translocation Factor (BTF) is a measure of the internal mobility of a given element across plant organs (Deng et al., 2004). The highest BTF recorded element is $\mathrm{N}$ for Paspalidium punctatum and $\mathrm{K}$ for Cyperus rotundus. Variation of BTF for the tested elements was narrow for Cyperus rotundus and the range was 0.68 to 1.86 whereas it was in the range of 0.67 to 2.23 for Paspalidium punctatum. For both the species, N, P, K, Ca, Mg can be considered as more mobile elements compared to tested heavy metals. For $\mathrm{Cd}$, As and $\mathrm{Pb}$, comparatively higher translocations were observed in Cyperus rotundus than those of Paspalidium punctatum though the results were not statistically significant.

The Biological concentration Factor $(\mathrm{BCF})$ is generally defined as the metal concentration ratio in root to soil. However, this study tested the BCF of nutrient parameters also in relation to tested plant species. The highest BCF was recorded for $\mathrm{K}$ by both the plants. Similarly, BAF which is the ratio of concentration of given element in shoot to soil, was also the highest for $\mathrm{K}$ in both plant species. Ca also had a considerable higher value of $\mathrm{BCF}$ and $\mathrm{BAF}$ in both plant species. A $\mathrm{BCF}$ value higher than one may indicate that a plant species could act as a hyperaccumulator (Bonanno and Cirelli, 2017). Therefore, both species could be considered as hyperaccumulator for $\mathrm{K}, \mathrm{Ca}$ and $\mathrm{Mg}$. A plant species that has both $\mathrm{BCF}$ and $\mathrm{BTF}>1$ has the potential of being use in phytoextration (Yoon et al., 2006). Hence, this study showed phytoextration ability of two species Paspalidium punctatum and Cyperus rotundus considering the tested elements $\mathrm{K}, \mathrm{Ca}$, $\mathrm{Mg}$ and their BCF and BTF.

Rather than these two species, effective accumulator of $\mathrm{N}$ and $\mathrm{P}$ may also be present in thaulla area and identification of their effectiveness in accumulating nutrients may be useful. Kao et al., (2003) showed different capabilities of retention of $\mathrm{N}$ and $\mathrm{P}$ of different wetland plant species. This study used only two abundant plant species, and it is suggested to use other available plant species in the natural habitat to evaluate the nutrients and also toxic heavy metal retention capabilities so that water resources planner can encourage growing of those aquatic plants with high capacities to accumulate agricultural pollutants in thaulla area. In addition, these plant species can be used as plants in constructed wetlands locally.

Table 03: Biological translocation factor, Biological concentration factor, Biological accumulation factor of Nutrient and heavy metal content of under Paspalidium punctatum and Cyperus rotundus

\begin{tabular}{lcccccc}
\hline & \multicolumn{3}{c}{ Paspalidium punctatum } & \multicolumn{3}{c}{ Cyperus rotundus } \\
\cline { 2 - 7 } Parameter & $\begin{array}{c}\text { Shoot:Root } \\
\text { (BTF) }\end{array}$ & $\begin{array}{c}\text { Root: Soil } \\
\text { (BCF) }\end{array}$ & $\begin{array}{c}\text { Shoot: Soil } \\
\text { (BAF) }\end{array}$ & $\begin{array}{c}\text { Shoot:Root } \\
\text { (BTF) }\end{array}$ & $\begin{array}{c}\text { Root: Soil } \\
\text { (BCF) }\end{array}$ & $\begin{array}{c}\text { Shoot: Soil } \\
\text { (BAF) }\end{array}$ \\
\hline $\mathrm{N} \%$ & $2.23 \pm 1.47$ & $0.54 \pm 0.56$ & $1.57 \pm 2.73$ & $1.53 \pm 1.24$ & $0.49 \pm 0.55$ & $0.72 \pm 2.96$ \\
$\mathrm{P}(\mathrm{mg} / \mathrm{kg})$ & $1.52 \pm 0.63$ & $0.53 \pm 0.18$ & $0.76 \pm 0.16$ & $1.67 \pm 0.76$ & $0.69 \pm 0.23$ & $1.07 \pm 0.37$ \\
$\mathrm{~K}(\mathrm{mg} / \mathrm{kg})$ & $1.96 \pm 0.95$ & $14.41 \pm 9.94$ & $22.34 \pm 11.1$ & $1.86 \pm 1.35$ & $15.18 \pm 7.57$ & $24.16 \pm 8.50$ \\
$\mathrm{Ca}(\mathrm{mg} / \mathrm{kg})$ & $1.24 \pm 0.37$ & $2.52 \pm 1.02$ & $2.42 \pm 1.05$ & $1.17 \pm 0.48$ & $1.89 \pm 0.98$ & $2.13 \pm 1.11$ \\
$\mathrm{Mg}(\mathrm{mg} / \mathrm{kg})$ & $1.25 \pm 0.27$ & $1.67 \pm 0.71$ & $1.94 \pm 0.58$ & $1.31 \pm 0.44$ & $0.92 \pm 0.81$ & $1.21 \pm 0.69$ \\
\hline $\mathrm{Heavy}$ metal & & \multicolumn{7}{c}{} & & & \\
\hline $\mathrm{Cd}(\mathrm{ppb})$ & $0.67 \pm 0.34$ & $\mathrm{ND}$ & $\mathrm{ND}$ & $0.806 \pm 0.41$ & $\mathrm{ND}$ & $\mathrm{ND}$ \\
$\mathrm{As}(\mathrm{ppb})$ & $0.77 \pm 0.26$ & $\mathrm{ND}$ & $\mathrm{ND}$ & $0.681 \pm 0.30$ & $\mathrm{ND}$ & $\mathrm{ND}$ \\
$\mathrm{Pb}(\mathrm{ppb})$ & $0.75 \pm 0.2$ & $0.02 \pm 0.02$ & $0.01 \pm 0.02$ & $0.809 \pm 0.26$ & $0.008 \pm 0.02$ & $0.006 \pm 0.01$ \\
\hline
\end{tabular}

Note: mean values $( \pm S D)$ 


\section{CONCLUSION}

This field study tested the nutrients and heavy metal accumulation of the most abundant two plant species Paspalidium punctatum and Cyperus rotundus in Thaulla area of Ulankulama tank. Results indicated that both species could be considered as hyperaccumulator for $\mathrm{K}, \mathrm{Ca}$ and $\mathrm{Mg}$. This study further showed that N, P, K, Ca, $\mathrm{Mg}$ can be considered as more mobile elements compared to tested heavy metals for both species. Moreover, As and Cd were not observed in detected amount in soils associated root zone of the plants, the presence of As and $\mathrm{Cd}$ in shoots and roots may be probably due to higher release rate of these elements from the soil and their bio accumulation. This study is the first study which attempted to find the phytoextraction abilities of soil nutrients and heavy metals and metalloids in thaulla area of small tank. There may be better hyperaccumulator plants for all nutrients which may not be abundant in thaulla area. Therefore, further studies are suggested to carry out tests of nutrients and heavy metal accumulation capabilities of thaulla plants especially in a controled environment and in thaulla area of other tanks.

\section{REFERENCES}

Abeysingha, N.S., Dassanayake, K.B. \& Weerarathna, C.S. (2018). Will restoration of ecological functions of tank cascade system contribute to reduce CKDu in Sri Lanka? a Review. Journal of environment management and sustainable development, 7 (3), pp.60-81 DOI: 10.5296/emsd. v7i3.13129.J.

Abeysingha, N.S., Jayenethithi, J.P.H.U., Kosgollegedara, E.J. \& Hammer, S. (2016). Variation in Soil Quality Parameters in the Thaulla Area of a Small Reservoir - A Case Study of Ulankulama Tank at Anuradhapura, Sri Lanka, Journal of Agricultural Physics. 16(1, 2), pp. 1-8.

Akinremi, O.O., Armisen, N., Kashem, M.A. \& Janzen, H.H. (2003). Evaluation of analytical methods for total phosphorus in organic amendments, Communications in Soil Science and Plant Analysis. 34 (19-20), pp. 2981- 2991.

Bonanno, G. (2013). Comparative performance of trace element bioaccumulation and biomonitoring in the plant species Typha domingensis, Phragmites australis and Arundo donax. Ecotoxicology and Environ. Safety. 97, pp. 124-130.

Bremner, J.M. and C.S. Mulvaney. 1982. Nitrogen-Total, pp. 595-624. In: A. L. Page, R.H. Miller, and D.R. Keeney (eds.), Methods of Soil Analysis. Part 2.2nd ed. Agronomy 9. American Society of Agronomy, Madison, WI.

Caçador L, .Neto J.M., Duarte B, Barroso D.V. Pinto M. \& Marques J.C. (2013). Development of an Angiosperm Quality Assessment Index (AQuA-Index) for ecological quality evaluation of Portuguese water bodies - a multi-metric approach, Ecological Indicators. 25, pp. $141-148$.

Chapman, H.D. \& P.F. Pratt (1961). Methods of analysis for soils, plant and water. University of California., Division of Agricultural Science

Deng, H., Yea, Z.H. \& Wong,M.H. (2004). Accumulation of lead, zinc, copper and cadmium by 12 wetland plant species thriving in metal-contaminated sites in China. Environmental Pollution.132, pp. 29-40.

FAO, 2018, Globally Important Agricultural Heritage Systems combining agricultural biodiversity, resilient ecosystems, traditional farming practices and cultural identity, Retrieved from http:// www.fao.org/3/BU612EN/bu612en.PDF. 
González-Alcaraz M.N., Conesa H.M., Álvarez-Rogel, J. (2013) Nitrate removal from eutrophic wetlands polluted by metal-mine wastes: Effects of liming and plant growth. Journal of Environmental management. 128 Volume 128, pp. 964-972.

Gunapala, K. G .M. W.\& Abeysingha, N.S. (2019). Chemical precipitation function of Thaulla area in small tank in Sri Lanka, Resources and Environment. 9(3), pp. 49-57.

Jenssen, P., Maehlum, T. \& Krogstad, T. (1993). Potential Use of Constructed Wetlands for Wastewater Treatment in Northern Environments. Water Science and Technology. 28,pp.149-157.

Kao, J.T., Titus, J.E. \& Zhu, W.X. (2003). Differential nitrogen and phosphorus retention by five wetland plant species, Wetlands. 23(4), pp. 979-987.

Karunadasa, R.M.S.S.B. \& Duminda, D.M.S. (2013). Soil fertility of major Maize (Zea mays L.) growing areas in Anuradhapura district. Undergraduate Research Symposium - July 2013, Department of Soil and Water Resources Management, Faculty of Agriculture, Rajarata University of Sri Lanka. Available at: http://repository.rjt.ac.lk:8080/xmlui/handle/12345678 9/522, Accessed 14 June 2017.

Li, H., Shi. A., Li. M. \& Zhang, X. ( 2013). Effect of pH, Temperature, Dissolved Oxygen, and Flow Rate of Overlying Water on Heavy Metals Release from Storm Sewer Sediments Journal of Chemistry, http://dx.doi.org/10.1155/2013/434012

Madduma Bandara, C.M. (1985). Catchment ecosystems and village tank in the dry zone of Sri Lanka: A time-tested system of land and water management. In: Lundquist, J.,Lohm, U. and Falkenmark, M. (Eds.), Strategies for river basin development. D. Reidel Publishing Company, Germany (1985), 99-103. Available at: https://link.springer.com/chapter/10.1007/978-94-009-5458-8_11, Accessed 14 June 2019.

Mahatantila, K., Chandrajith, R., Jayasena, H.A.H. \& Ranawana, K.B. (2008) Spatial and temporal changes of hydrogeochemistry in ancient tank cascade systems in Sri Lanka: evidence for a constructed wetland. Water and Environment Journal 22(1), pp.17-24. DOI: https://doi. org/10.1111/j.1747-6593.2007.00077.x.

Maiti, S.K. \& Jaiswal, S. (2008). Bioaccumulation and translocation of metals in the natural vegetation growing on fly ash lagoons: a field study from Santaldih Thermal Power Plant, West Bengal, India. Environmental Monitoring and Assessment 136(1-3), pp.355-370

Malaviya, P \& Singh A. (2012). Constructed Wetlands for Management of Urban Stormwater Runoff,Critical Reviews in Environmental Science and Technology.42(20), pp.21532214, DOI: 10.1080/10643389.2011.574107

Nandasena, K.A.(2002). Nitrogen status and its supplying capacity of tropical soils of Sri Lanka. Sri Lanka Journal of Agricultural Science 39: 116-126. DOI: https://doi.org/10.31357/fesympo. v0i0.1438.

Phillips, D.P., Human, L.R.D. \& Adams, J.B. ( 2015). Wetland plants as indicators of heavy metal contamination. Marine Pollution Bulletin. 92,pp. 227-232.

Reddy, K.R. \& D’Angelo, E.M.(1997). Biogeochemical indicators to evaluate pollutant removal efficiency in constructed wetlands. Water Science and Technology 35(5), pp 1-10. DOI: https:// doi.org/10.1016/S0273-1223(97)00046-2.

Rowell, D.L. (1994). Soil Science: Methods and Applications. Longman Publishers Ltd, 169pp 
SERAS (2006). Standard Operating Procedures: Determination of Metals by Inductively Coupled Plasma (ICP) Methods. Retrieved on August 22017 from: https://clu-in.org/download/ ert/1811-r30.pdf.

Yoon,J., Cao, X., Zhou, Q. \& Ma, L.Q. (2006).Accumulation of $\mathrm{Pb}, \mathrm{Cu}$, and $\mathrm{Zn}$ in native plants growing on a contaminated Florida site. Science of the Total Environment. 368, pp. 456-464

Zedler J (2010). Tussock sedge a restoration super plant? https://arboretum.wisc.edu/content/ uploads/2015/04/22_ArbLeaflet.pdf

Wijesundara, W.M.G.D., Nandasena, K.A. \& Jayakody, A.N., 2012, Spatial and temporal changes in Nitrogen, Phosphorus and Potassium concentration in water in the Thirappane tank cascade in dry zone of Sri Lanka. Journal of Environmental Professionals Sri Lanka. 1(1): 70-81. DOI: http://dx.doi.org/10.4038/jepsl.v1i1.5143. 